\title{
Comparative Study of Different Disinfectant Solutions on Reducing Catheter Associated Urinary Tract Infections Among Critical Patients
}

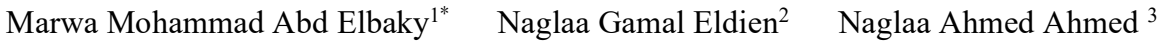 \\ Eman Fadl Abd El khalik ${ }^{4}$ \\ 1.Lecturer in Medical Surgical Nursing (Critical Care Nursing), Faculty of Nursing. Minia University, Egypt \\ 2 .Lecturer of Critical Care and Emergency Nursing, Faculty of Nursing. Sohage University, Egypt \\ 3. Lecturer of Critical Care and Emergency Nursing, Faculty of Nursing.Assuit University, Egypt \\ 4 .Lecturer of Medical Surgical Nursing, Faculty of Nursing. Minia university, Egypt
}

\begin{abstract}
Catheter associated urinary tract infection (CAUTI) is one of the most common hospital acquired infection. Several antiseptic agents as (chlorhexidine, water, and povidone iodine) are available prior the insertion of urinary catheters to reduce infection among critical patients. Aim: compare the effect of different disinfectant solutions on reducing (CAUTI) among critical patients. Design: Quasi experimental was utilized at the cardiology care unit (CCU) and followed up at medical ward of Sohage University Hospital, Egypt. Purposive sample (210) cardiac patients conveniently selected and divided equally to three groups had newly inserted urethral catheter. Group (A) used chlorhexidine 5\%, Group (B) used soap and water and Group (C) used $10 \%$ povidone Iodine solution in the perineal and urethral meatus care before insertion. Results: the majority of the studied sample were male aged $(38.77 \pm 9.95,36.69 \pm 11.1$ and $36.77 \pm 11.4)$ years. Majority of three groups had no fever at $1^{\text {st }}$ observation. Group $\mathrm{C}$ had dysuria from the $1^{\text {st }}$ till the $3^{\text {rd }}$ time of observation $(53,77 \& 81.4 \%)$. High percentage of group $\mathrm{C}$ had positive urine culture at the three observations $(51.4,71.4, \& 78.5 \%)$. High correlation between used soap and water (group B) and body temperature, dysuria, and low correlation between purulent drainage with chlorhexidine group (A). Conclusion: using chlorhexidine gluconate and soap and water were the best methods that can be used in perineal care before catheter insertion and maintenance care than povidone iodine solution.
\end{abstract}

Keywords: Comparative, Disinfectant, Solutions, Catheter, Infection, Urinary and Critically.

DOI: $10.7176 / \mathrm{JHMN} / 73-14$

Publication date: April $30^{\text {th }} 2020$

\section{Introduction}

Hospital acquired infection (HAI) affect approximately $30 \%$ of intensive care unit (ICU) patients. The World Health Organization (WHO) estimates that each year, hundreds millions patients around the world affected by HAI. Patients in ICU have a high risk for urinary tract infections (UTIs) which considered the most common type of HAIs. 93,300 UTIs occurred in acute care settings as ICUs. Virtually all healthcare-associated UTIs are caused by instrumentation of the urinary tract. Approximately $12 \%-16 \%$ of adult hospital inpatients will have an indwelling urinary catheter (IUC) at some time during their hospitalization. ${ }^{[1]}$ Catheter associated urinary tract infection (CAUTI) defined as patients who had a current urinary catheter (UC) in place or had previously inserted a catheter up to $48 \mathrm{~h}$ before the onset of the UTI and who met the clinical, laboratory, and microbiological criteria. ${ }^{[2], ~[3] ~ R i s k ~ f a c t o r ~ o f ~ C A U T I ~ a r e ~ a d v a n c e d ~ a g e, ~ u r i n a r y ~ f u n c t i o n ~ a b n o r m a l i t i e s, ~ p r e s e n c e ~ o f ~ c h r o n i c ~ d i s e a s e s, ~}$ immune dysfunction, female sex, obesity, duration of catheter use, prolonged immobility, surgical trauma, prolonged use of antibiotics, moreover, urinary catheterization is often performed without a specific medical indication, increased length of stay at ICU or ward. [4]

Prevention of CAUTI can be applied through following guidelines of the center of disease control and prevention (CDC). ${ }^{[5]}$ This guidekines can be applicable in every ICU and include: catheter avoidance strategies, hand hygiene, perineal care, using sterile technique and equipment, meatal cleansing with disinfectant solutions (chlorhexidine, povidone iodine or soap and water) according to the hospital policy, use of one catheter per catheterization attempt, adequate balloon inflation, maintain collection bag lower than bladder level, not touch the ground, and daily necessity review to limit catheter days ${ }^{[5]}$. Many ICU implement the CDC guidelines for catheter insertion in order to improve patient outcomes. The CDC guidelines support that using disinfectant solution prior catheter insertion and in the prineal care an important item in preventing CAUTI rates. Literature tried to use povidone iodine solution to reduce the occurrence of CAUTI ${ }^{[6]}$. Although a previous study tried to assess the efficacy of per urethral cleaning with, chlorhexidine gluconate solution, and sterile water for the prevention of CAUTI $^{[7]}$. So that further investigation is needed to examine the efficacy of which one of the used solution on the prevention of CAUTI. 


\section{Significance}

Urinary tract infections (UTIs) are the fifth HAI among critically patients with an estimated 62,700 UTIs in ICUs. UTIs account for more than $9.5 \%$ of infections reported by acute care setting. Approximately $12 \%-16 \%$ of critical patients will have an indwelling urinary catheter at some time during stay in ICU, and each day the indwelling urinary catheter remains, a patient has a $3 \%-7 \%$ increased risk of acquiring CAUTI. These Complications associated with discomfort to the patient, increase hospital stay and increased cost and mortality rate. It has been estimated that each year, more than 13,000 deaths are associated with UTIs. ${ }^{[9]}$

Many hospitals and ICUs lack of standardized protocols about effective care to reduce CAUTI among their patients. On the other hand, CDC found that implementation of CAUTI guidelines was associated with a $12 \%$ decrease in the CAUTI rate and $20 \%$ reduction in catheter insertion rates. ${ }^{[10]}$ From the researcher's observations, it was found that ICU nurses did not apply standard methods during urinary catheter insertion. Many ICUs and nurses uses povidone iodine solution during perineal and urethral care before catheter insertion and the other use soap and water before insertion and care. So the following study will be applied to evaluate which solution will reduce CAUTI manifestation among critical patients.

\section{Aim of the study}

To compare the effect of different disinfectant solutions on reducing catheter associated urinary tract infection among critical patients.

\section{Research hypotheses:}

To fulfill the aim of the study the following research hypothesis were formulated:

- Chlorhexidine solution will be the first in reducing CAUTI rates than other two solutions

- Using soap and water will reduce CAUTI rates, after Chlorhexidine solutions.

- Using Povidone iodine will have a higher incidence of CAUTI than other two solutions.

\section{Patient and Methods}

Quasi experimental study was carried out at the cardiology Care Unit (CCU), and medicine in patient ward, of Sohage University Hospital of Egypt at the period from January 2019 to August 2019. A purposive sample included 210 cardiac patients. The sample size was selected by taking $30 \%$ from the total number of admitted cases in the last year from $1^{\text {st }}$ of January 2018 to the last of December 2018 . The sample were selected conveniently and divided equally into three groups (Group A) used chlorhexidine 5\% solution, (Group B) used soap and water and (Group C) used $10 \%$ povidone iodine solution in the perineal and urethral meatus care before insertion. The inclusion criteria included all newly admitted cardiac patients, conscious adult, age between (18 - 60 years), hade newly inserted urethral catheter for more than 48 hours. Patients from both sex (male and female), able to communicate. The exclusion criteria: patient's with UTI or any other systemic infection, comatose intubated patients and Immune compromised patients.

Tools of the study: two tools were formulated by the researchers after extensive literature review. Tool one Patient general assessment questionnaire included two parts. $1^{\text {st }}$ part: Patient's socio-demographic data as, patient's age, sex, level of education. $2^{\text {nd }}$ part included medical diagnosis, risk factors and size of urinary catheter.

Tool two: CAUTI assessment questionnaire: used to assess CAUTI clinical and laboratory manifestations it includes two parts $\mathbf{1}^{\text {st }}$ part: the clinical manifestations as fever (equals or more than $38^{\circ} \mathrm{C}$, suprapubic pain, dysuria, Urethral erythema, purulent drainage around the catheter exit, etc. $\mathbf{2}^{\text {nd }}$ part: the laboratory test as urine analysis to detect presence of bacteria, pyuria (pus cells $\geq 3 / \mathrm{ml}$ in unspun urine), urine culture to stand on the presence of urinary tract infection, and white blood cells count (WBC) to prove presence of infection.

Ethical consideration: An official permission was granted from the director of Sohage University Hospital of Egypt, head of the cardiology unit, medical ward department and the unit head nurse to conduct the study. Written informed consent was obtained by researcher from patients after explanation of the aim of the study. confidentiality of data, privacy, voluntary participation and right to refuse to participate in the study was informed to them by the researcher through personal communication.

\section{Validity and Reliability}

Study tools were tested for content validity by a jury panel of five experts in the field of the study and the necessary modifications were done. The reliability test was estimated using Cronbach's Alpha Coefficient test for the two tools which indicated that the questionnaires were highly reliable $(0.735$ and 0.750$)$ respectively. Pilot study was done on $10 \%(21)$ of patients to test the feasibility of the study and applicability of the tool and there is no modifications done.

\section{Research Procedure}

The researcher assessed all patients from the three groups whom having the inclusion criteria immediately after 
the $1^{\text {st }}$ day of admission and after they become clinically stable using tool one $\left(1^{\text {st }}\right.$ and $2^{\text {nd }}$ part $)$. After obtaining the informed consent, patients were consecutively randomized to three groups (Group A) whom received perineal and urethral meatus care using chlorhexidine disinfectant solution (5\%). (Group B) received perineal and urethral meatus care using soap and water. (Group C) received perineal and urethral meatus care using $10 \%$ povidone iodine disinfectant solution. Urinary catheter insertion and maintenance care were applied to all groups according to the Centers for Disease Control and Prevention, 2015 (CDC) ${ }^{(11)}$ nursing guidelines and recommendations of care. The insertion and maintenance care steps were done at the morning shift daily for all patients of the three groups by the researchers.

Researcher ensured and applied all the following steps of the CDC guide lines before catheter insertion for the three groups: (Confirm doctor order, use the smallest effective catheter size. Explain the procedure, and its potential complications to the patient and/or family. Ensure privacy and good lighting. Perform hand hygiene. The pre-urethral cleansing was done for each group using one solution from the above listed. Opening sterile catheterization kit on a clean bedside table, using sterile technique. Ensure all supplies are conveniently positioned. Put on sterile gloves and all patients were draped.

The solution was prepared for each group \{Group A, chlorhexidine, group B soap and water and povidone iodine for group $\mathrm{C}$ \} and perineal care was done, cleansing the perineal area, moving from front to back in the female and in circular motion from the top to down in male patients). With dominant (sterile) hand, cleaned the meatus opening with the same antiseptic solution for each group. A new cotton ball used each time. The disinfectant solution was left to dry. After that (gloves was removed and hand hygiene was performed. Another sterile gloves were done; sterile lubricant was applied to the catheter tip. The catheter was attached to drainage system, and the drainage bag emptying port was clamped. With the non-dominant hand, urethral meatus was identified. With the dominant (sterile) hand, the catheter inserted slowly into the urethra until there return of urine. Then it was advanced 2-3 inches more again. The catheter left in bladder, the catheter balloon was fully inflated with entire volume of supplied sterile water or normal saline in a prefilled syringe. The catheter was secured to patient's inner thigh with adhesive tape for female and at the lower abdomen in male. Gloves was removed and hand hygiene performed. The drainage bag was kept below the level of the bladder. Patients were covered immediately after finishing the procedure for privacy.

All groups were received daily disinfection and maintenance care of the urethral meatus, catheter tube with its irrigation and urine port using the same disinfectant solution for each one. The urine collection bag was changed daily. The urine evacuation port was disinfected with the same solution for each group also. Finally the three groups were evaluated using tool two $\left(1^{\text {st }}\right.$ part and $2^{\text {nd }}$ part $)$ three times, first and second at the $3^{\text {rd }}, 6^{\text {th }}$ day at the CCU but the third time was done at the $9^{\text {th }}$ day after transferring patients to the medical ward when they became clinically stable (after spending 7 days in the CCU). All patients continued their medical and nursing care and the follow up evaluation at the medical in patient department. Patient were assessed to evaluate the efficacy of the three used solutions before, during and after catheter insertion on reducing CAUTI.

\section{Data Analysis}

Data was tabulated, coded, entered and analyzed using the Statistical Package for Social Science (SPSS) software version 25. Frequency and percentage distribution were used to present quantitative data as mean and standard deviation. 
Results

Table (1) Frequency distribution of sociodemographic and medical characteristics of the patient's groups. Total number (210) each group (70).

\begin{tabular}{|l|c|c|c|}
\hline \multicolumn{1}{|c|}{ Variables } & $\begin{array}{c}\text { Chlorhexidine } \\
\text { A }\end{array}$ & $\begin{array}{c}\text { Soap and water } \\
\text { B }\end{array}$ & $\begin{array}{c}\text { Povidone Iodine } \\
\text { C }\end{array}$ \\
\hline $\begin{array}{l}\text { Age } \\
\text { Mean } \pm \text { SD }\end{array}$ & $38.77 \pm 9.95$ & $36.69 \pm 11.1$ & $36.77 \pm 11.4$ \\
\hline Sex & No (\%) & No (\%) & No (\%) \\
\hline Male & $40(57.1)$ & $44(63)$ & $40(57)$ \\
\hline Female & $30(43)$ & $26(37)$ & $(42.5)$ \\
\hline Risk factors & $14(20)$ & $17(24)$ & $20(28.5)$ \\
\hline Previous hospital admission. & $27(38.5)$ & $28(40)$ & $29(41)$ \\
\hline Previous systemic infection. & $29(41)$ & $25(36)$ & $(30)$ \\
\hline Previous antibiotic therapy. & $28(40)$ & $29(41)$ & $30(43.5)$ \\
\hline Obesity . & $25(36)$ & $14(20)$ & $18(26)$ \\
\hline Medical diagnosis & $13(18.5)$ & $16(23)$ & $16(23)$ \\
\hline Angina & $15(21.4)$ & $18(26)$ & $14(20)$ \\
Myocardial infarction & $17(24.2)$ & $22(31.4)$ & $12(17.1)$ \\
Heart failure & \multicolumn{3}{|l}{} \\
Heart block &
\end{tabular}

Table (1): shows that; most of the studied sample were male their mean age and standard deviation was $(38.77 \pm$ $9.95,36.69 \pm 11.1$ and $36.77 \pm 11.4$ ) years. In relation to the risk factors this table shows, about half of the studied groups had previous history of systemic infection other than the urinary tract infection. Also about half of the studied groups had a previous history of antibiotic therapy.

Table (2): Percentage distribution of clinical manifestations of UTI between the three groups (70 each group).

\begin{tabular}{|c|c|c|c|c|c|c|c|c|}
\hline \multirow[t]{4}{*}{ Variables } & & & & & & & \multirow[t]{4}{*}{$\chi^{2}$ test } & \multirow[t]{4}{*}{ P value } \\
\hline & \multirow{2}{*}{\multicolumn{2}{|c|}{$\begin{array}{c}\text { Groups A } \\
\text { Chlorhexidine } \\
\text { No }(\%)\end{array}$}} & \multirow{2}{*}{\multicolumn{2}{|c|}{$\begin{array}{c}\text { Groups B } \\
\text { Soap and water } \\
\text { No (\%) }\end{array}$}} & \multirow{2}{*}{\multicolumn{2}{|c|}{$\begin{array}{c}\text { Groups C } \\
\text { Povidone iodine } \\
\text { No (\%) }\end{array}$}} & & \\
\hline & & & & & & & & \\
\hline & Yes & No & Yes & No & Yes & No & & \\
\hline $\begin{array}{l}\text { - Fever }>\mathbf{3 8}{ }^{\mathrm{oC}} \\
1^{\text {st }} \text { time at } 3^{\text {rd }} \text { day }\end{array}$ & $24(34.3)$ & $46(66)$ & $18(28.6)$ & $52(71.4)$ & $14(24.3)$ & $56(76)$ & 3.70 & 0.15 \\
\hline $2^{\text {nd }}$ time at $6^{\text {th }}$ day & $31(44.2)$ & $39(56.2)$ & $27(38.5)$ & $43(61.4)$ & $42(60)$ & $28(40)$ & 6.91 & 0.32 \\
\hline $3^{\text {rd }}$ time at $9^{\text {th }}$ day & $38(54.2)$ & $32(46.1)$ & $27(38.5)$ & $43(61.4)$ & $58(83.4)$ & $12(17.2)$ & 29.1 & $0.001 * *$ \\
\hline $\begin{array}{l}\text { Suprapubic pain } \\
1^{\text {st }} \text { time }\end{array}$ & $6(8.5)$ & $64(91.4)$ & $16(23.3)$ & $54(77)$ & $7(10)$ & $63(90)$ & 7.28 & $0.026^{*}$ \\
\hline $2^{\text {nd }}$ time & $35(50)$ & $35(50)$ & $23(33.3)$ & $47(67.1)$ & $46(66.1)$ & $24(34.2)$ & 15.1 & $0.001 *$ \\
\hline $3^{\text {rd }}$ time & $42(60)$ & $28(40)$ & $45(64.2)$ & $25(36.1)$ & $59(84.2)$ & $11(16.1)$ & 11.1 & $0.004 *$ \\
\hline $\begin{array}{l}\text { Dysuria } \\
1^{\text {st }} \text { time }\end{array}$ & $12(17.1)$ & $58(83.5)$ & $10(14.2)$ & $60(86)$ & $37(53)$ & $33(47)$ & 32.0 & $0.003 *$ \\
\hline $2^{\text {nd }}$ time & $11(15.7)$ & $59(84.2)$ & $16(23.3)$ & $54(77)$ & $51(73)$ & $19(27.1)$ & 58 & $0.001 * *$ \\
\hline $3^{\text {rd }}$ time & $32(46)$ & $38(54)$ & $8(11.4)$ & $62(88.5)$ & $57(81.4)$ & $13(18.6)$ & 69.0 & $0.002 * *$ \\
\hline $\begin{array}{l}\text { Urethral erythema } \\
1^{\text {st }} \text { time }\end{array}$ & $15(21.4)$ & $55(78.5)$ & $23(33.3)$ & $47(67)$ & $47(67.1)$ & $23(33.3)$ & 32.8 & $0.003 * *$ \\
\hline $2^{\text {nd }}$ time & $24(34.2)$ & $46(66.2)$ & $31(44.2)$ & $39(56.1)$ & $42(60)$ & $28(40)$ & 9.46 & $0.009^{*}$ \\
\hline $3^{\text {rd }}$ time & $28(40)$ & $42(60)$ & $31(44.2)$ & $39(56.1)$ & $42(60)$ & $28(40)$ & 6.21 & $0.045^{*}$ \\
\hline $\begin{array}{l}\text { Purulent drainage } \\
1^{\text {st }} \text { time }\end{array}$ & $15(21.4)$ & $55(78.5)$ & $10(14.2)$ & $60(86)$ & $24(34.3)$ & $46(66)$ & 8.03 & $0.018^{*}$ \\
\hline $2^{\text {nd }}$ time & $31(44.2)$ & $39(56)$ & $18(26)$ & $52(74.2)$ & $51(73.5)$ & $19(27.1)$ & 31.6 & $0.001 * *$ \\
\hline $3^{\text {rd }}$ time & $37(53)$ & $33(47)$ & $23(33)$ & 47 (67) & $51(73.5)$ & $19(27.1)$ & 22.4 & $0.002 * *$ \\
\hline
\end{tabular}

$\chi^{2}=$ Chi-square test - Independent samples. Statistical significant difference * $(\mathbf{P}<0.005)$

Table 2: Majority of the three groups had no fever after the $1^{\text {st }}$ three days of using disinfectant solutions. But at the $9^{\text {th }}$ day only group be more than half of them had no fever. Regarding dysuria, group B had the lowest percentage of dysuria at the $1^{\text {st }}$ and $3^{\text {rd }}$ time of the study $(14$ and $11 \%)$ respectively. In relation to purulent drainage at the $1^{\text {st }}$ and $2^{\text {nd }}$ time a high percentage of both groups (A and $\left.\mathrm{B}\right)$ had no presence of it $(78.5,86 \%)$ respectively 
and $(56,74.2 \%)$ respectively. There was statistical significant difference between them presented by $\mathrm{P}$ value $(0.001,0.002)$ respectively at the $2^{\text {nd }}$ and $3^{\text {rd }}$ time.

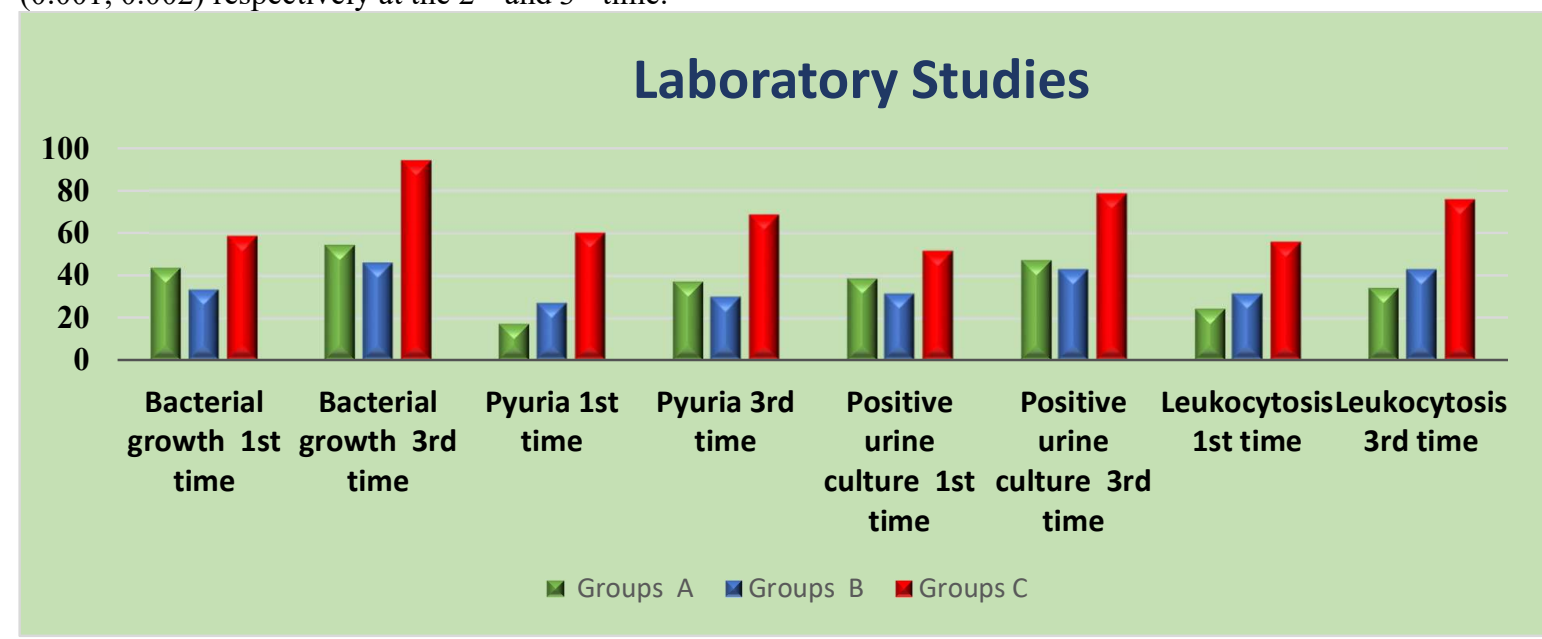

Figure (1): Comparison between three groups regarding laboratory studies.

Figure 1: shows bacterial growth was present in a very low percentage in the urine test of group $B$ at the $1^{\text {st }}$ and $3^{\text {rd }}$ time of observation ( $33 \& 46 \%$ ). A high percentage of group $\mathrm{C}$ had positive urine culture at the $1^{\text {st }}$ and $3^{\text {rd }}$ observations $(51 \& 78.5 \%)$. There was statistical significance difference between the three groups of observation presented by $\mathrm{P}$ value less than $(0.05)$ in the previously listed variables.

Table 3: Correlation between age and sex among three groups of the study and clinical manifestations

\begin{tabular}{|c|c|c|c|c|c|c|c|}
\hline \multirow{2}{*}{\multicolumn{2}{|c|}{ Variable }} & \multirow{2}{*}{\multicolumn{3}{|c|}{ Age }} & \multirow{2}{*}{\multicolumn{3}{|c|}{ Sex }} \\
\hline & & & & & & & \\
\hline & & Chlorhexidine & $\begin{array}{l}\text { Soap } \\
\text { and } \\
\text { water }\end{array}$ & $\begin{array}{l}\text { Povidone } \\
\text { iodine }\end{array}$ & Chlorhexidine & $\begin{array}{l}\text { Soap } \\
\text { and } \\
\text { water }\end{array}$ & $\begin{array}{l}\text { Povidone } \\
\text { iodine }\end{array}$ \\
\hline $\begin{array}{l}\text { Fever morethan381st } \\
\text { day }\end{array}$ & $\begin{array}{l}\mathrm{R} \\
\mathrm{P}\end{array}$ & $\begin{array}{l}.035 \\
.773\end{array}$ & $\begin{array}{l}.129- \\
.288\end{array}$ & $\begin{array}{l}.260 * \\
.030\end{array}$ & $\begin{array}{l}.017- \\
.891\end{array}$ & $\begin{array}{l}.062- \\
.607\end{array}$ & $\begin{array}{l}.177 \\
.143\end{array}$ \\
\hline Leuchocytosis $2^{\text {nd }}$ day & $\begin{array}{l}\mathrm{R} \\
\mathrm{P}\end{array}$ & $\begin{array}{l}.172- \\
.154\end{array}$ & $\begin{array}{l}.336-* * \\
.004\end{array}$ & $\begin{array}{l}.147- \\
.226\end{array}$ & $\begin{array}{l}.443-* * \\
.000\end{array}$ & $\begin{array}{l}.036 \\
.766\end{array}$ & $\begin{array}{l}.287-* \\
.016\end{array}$ \\
\hline Supapubic2nd & $\begin{array}{l}\mathrm{R} \\
\mathrm{P}\end{array}$ & $\begin{array}{l}.029 \\
.812\end{array}$ & $\begin{array}{l}.091 \\
.451\end{array}$ & $\begin{array}{l}.007- \\
.957\end{array}$ & $\begin{array}{l}.058- \\
.635\end{array}$ & $\begin{array}{c}.349-* * \\
.003 \\
\end{array}$ & $\begin{array}{l}.043- \\
.721 \\
\end{array}$ \\
\hline Frequancy2nd & $\begin{array}{l}\mathrm{R} \\
\mathrm{P}\end{array}$ & $\begin{array}{l}.124 \\
.308\end{array}$ & $\begin{array}{l}.219 \\
.068\end{array}$ & $\begin{array}{l}.142- \\
.242\end{array}$ & $\begin{array}{l}.041 \\
.738\end{array}$ & $\begin{array}{l}.096- \\
.428\end{array}$ & $\begin{array}{c}.452 * * \\
.000\end{array}$ \\
\hline Dysuria2 & $\begin{array}{l}\mathrm{R} \\
\mathrm{P}\end{array}$ & $\begin{array}{l}.236-* \\
.049\end{array}$ & $\begin{array}{c}.351-* * \\
.003 \\
\end{array}$ & $\begin{array}{l}.142- \\
.241\end{array}$ & $\begin{array}{l}.136- \\
.262\end{array}$ & $\begin{array}{l}.004 \\
.974\end{array}$ & $\begin{array}{l}.009 \\
.939 \\
\end{array}$ \\
\hline Urethralerythemq2nd & $\begin{array}{l}\mathrm{R} \\
\mathrm{P}\end{array}$ & $\begin{array}{l}.041- \\
.735\end{array}$ & $\begin{array}{c}.318-* * \\
.007\end{array}$ & $\begin{array}{l}.035 \\
.775\end{array}$ & $\begin{array}{l}.104 \\
.390\end{array}$ & $\begin{array}{c}.328-* * \\
.006\end{array}$ & $\begin{array}{l}.177- \\
.143\end{array}$ \\
\hline Purulent drainage2nd & $\begin{array}{l}\mathrm{R} \\
\mathrm{P}\end{array}$ & $\begin{array}{l}.052- \\
.668 \\
\end{array}$ & $\begin{array}{c}.345 * * \\
.003\end{array}$ & $\begin{array}{l}.101 \\
.408 \\
\end{array}$ & $\begin{array}{l}.274^{*} \\
.022\end{array}$ & $\begin{array}{l}.046- \\
.703\end{array}$ & $\begin{array}{l}.121- \\
.320\end{array}$ \\
\hline Bacterial growth2nd & $\begin{array}{l}\mathrm{R} \\
\mathrm{P}\end{array}$ & $\begin{array}{l}.017 \\
.888\end{array}$ & $\begin{array}{l}.244^{*} \\
.042\end{array}$ & $\begin{array}{l}.075- \\
.539\end{array}$ & $\begin{array}{l}.125 \\
.303\end{array}$ & $\begin{array}{l}.262 * \\
.028\end{array}$ & $\begin{array}{c}.462-* * \\
.000\end{array}$ \\
\hline Pyuria pus2nd & $\begin{array}{l}\mathrm{R} \\
\mathrm{P}\end{array}$ & $\begin{array}{l}.015- \\
.901\end{array}$ & $\begin{array}{l}.190- \\
.115\end{array}$ & $\begin{array}{l}.116- \\
.338\end{array}$ & $\begin{array}{l}.367-* * \\
.002\end{array}$ & $\begin{array}{l}.104 \\
.393\end{array}$ & $\begin{array}{l}.222- \\
.065\end{array}$ \\
\hline $\begin{array}{l}\text { Positive urine } \\
\text { culture2nd }\end{array}$ & $\begin{array}{l}\mathrm{R} \\
\mathrm{P}\end{array}$ & $\begin{array}{l}.031 \\
.801\end{array}$ & $\begin{array}{l}.104 \\
.393\end{array}$ & $\begin{array}{l}.210- \\
.081\end{array}$ & $\begin{array}{l}.037- \\
.764\end{array}$ & $\begin{array}{l}.022- \\
.859\end{array}$ & $\begin{array}{l}.219- \\
.068\end{array}$ \\
\hline
\end{tabular}

Table 3: shows high correlation between soap and water (group B) and normal body temperature, leukocytosis, dysuria, urethral erythema, and low in Purulent drainage with chlorhexidine (group A), pus and low in Suprapubic pain, with povidone iodine (group C) and show statistical significant when used soap and water with group B.

\section{Discussion}

Urinary tract infections (UTIs) is the most common HAI, (60\% to $80 \%)$ of UTI results from the presence of indwelling urinary catheters. Previous study reported increase in UTI when using urethral catheter increases [9]. Finding the of the present study revealed most of the admitted cases to the CCU were male patients their mean age $(38.77 \pm 9.95-36.69 \pm 11.1$ and $36.77 \pm 11.4)$ this result because male had high incidence of cardiac diseases than 
women. This result is in line with Wilson ${ }^{[12]}$ who reported that cardiac disease is the killer number one for men. But Bonkat ${ }^{(13)}$ reported that, majority of patients whom complained from UTI were female during hospital stay because of their anatomical structure. Brett ${ }^{[14]}$ indicated that, women have a lifetime risk of over $(50 \%)$ of developing UTI in ICU. In relation to risk factors the current study revealed that $(100 \%)$ of the patients were cardiac and about half of the studied groups had previous history of systemic infection. Also about half of the studied groups had a previous history of antibiotic therapy. The result of the present study agrees with Kriegel [15] and Duygu ${ }^{[16]}$ mentioned that presence of chronic disease as myocardial infarction and previous history of antibiotic therapy increases the risk of CAUTI.

Finding of the current study revealed at the ( $2^{\text {nd }}$ and $3^{\text {rd }}$ time $)$ of evaluation, more than half of the soap and water group (B) had normal temperature but at the same time the majority of povidone iodine group (C) had fever from the $2^{\text {nd }}$ till $3^{\text {rd }}$ time of the study. Tucson ${ }^{[17]}$ reported that all patients with urinary catheters may only experience fever as a symptom of infection. The present study also similar to Düzkaya ${ }^{[7]}$ who found that both groups whom received pre-urethral care with chlorhexidine and sterile water, a few number of them experienced manifestations of CAUTI than the povidone iodine group. As regard to suprapubic pain, it was observed about half of soap and water group and the chlorhexidine group had no pain at the suprapubic area. While at the $9^{\text {th }}$ day of the study the majority of the povidone iodine group had it. Dysuria was observed in low percentage within soap and water group and chlorhexidine groups. But the povidone iodine group had dysuria at three times of observation. This results because soap and water and chlorhexidine were more safe than the povidone iodine.

This result agrees with Clark ${ }^{[\mathbf{1 8}]}$ who documented that UTI can lead to such manifestations as dysuria, cystitis, gram-negative bacteremia, and cause discomfort to the patients, prolonged hospital stay, and increased cost and mortality. Urethral erythema was observed in low percentage within chlorhexidine group than the povidone iodine group. As regard to purulent drainage it was observed in soap and water group but chlorhexidine group had no presence of it unlike the povidone iodine group. This results agree with Brett ${ }^{[14]}$ who reported that common symptoms of CAUTI include a strong, frequent urge to urinate, a painful, urethral erythema and dysuria. UTI is usually diagnosed based on symptoms and testing of a urine sample. UTIs can be cured within 2 to 3 days of treatment.

Gould ${ }^{[19]}$ documented that using chlorhexidine solution versus iodine solution before urinary catheter insertion in 19 patients with spinal cord injury. They found the amount of bacteriuria was reduced in 14 patients. This result also in line with Yulong ${ }^{[3]}$ who reported that Thirty-three studies (6490 patients) with three different methods of urethral cleaning versus disinfection were eligible for inclusion showed that chlorhexidine ranked first then sterile water and the last one is povidone iodine. Finding of current study revealed bacterial growth was present in a very low percentage in the urine test of soap and water group at the three times of observation then the chlorhexidine group less than half of them had bacterial growth at the $1^{\text {st }}$ and $2^{\text {nd }}$ time only but at the $3^{\text {rd }}$ time about half of them had bacterial growth in their urine analysis. In relation to presence of pus cells in the urine it was observed that most of the povidone iodine group had presence of it in their urine analysis at the three times of observation. A high percentage of the povidone iodine group had positive urine culture at the three observations.

Also in agreement with Yulong ${ }^{[3]}$ Elham ${ }^{[20]}$ and Hua ${ }^{[21]}$ whom reported that using chlorhexidine for cleaning prior catheter insertion decreased the incidence of UTI and has the potential to improve patient safety than povidone iodine. Furthermore, the intervention is likely to be cost-effective. Finding of the present study demonstrate that povidone-iodine group had presence of leukocytosis) at the three observation of the study. This results agree with Duygu ${ }^{[16]}$ who reported that UTI occurred in patients whom use the povidone-iodine group than other disinfectant types. Finding of the present study tried to prove that using povidone iodine in urethral cleansing is lower in its efficiency than using soap and water or chlorhexidine. At the $3^{\text {rd }}$ time of evaluation it was observed that soap and water and the chlorhexidine groups had lower manifestations of CAUTI than the povidone iodine group. Also the present study did not prove that chlorhexidine is the best or soap and water is the more cost effective because of the lower sample size. But the current study tried to document that using either soap and water or chlorhexidine will decrease CAUTI among critical or in ward patients than povidone iodine. The present study results were in line with Thomas ${ }^{[22]}$ who documented that periurethral cleaning with sterile water versus $0.1 \%$ chlorhexidine gluconate in adult women has low percent of bacterial presence in urine. This results disagreement with Kara ${ }^{[23]}$ who found that no statistically significant differences in UTI occurrences comparing sterile water, a povidone-iodine solution, and a chlorhexidine gluconate solution for periurethral cleansing prior to indwelling catheterization.

The present study agreed with Madeleine ${ }^{[24]}$ who reported that the majority of patients reduced their bacterial counts in group who use bladder irrigation with chlorhexidine. However, Richard ${ }^{(25)}$ documented that urethral irrigation with chlorhexidine solution lead to reduction of symptomatic UTI in patients and significantly reduces urine bacterial count in some patients. Another study of Fasugba ${ }^{[26]}$ who agree with our studies reported that reduction in the incidence of CAUTI might tempt critical care nurse to use a $0 \cdot 1 \%$ chlorhexidine solution for urethral cleaning instead of care using saline solution before urinary catheterization. Also agree with the present study in relation to finding no significant difference of using chlorhexidine in meatal cleaning before urinary 
catheter insertion and a non-antiseptic agent as (tap water and soup) in reducing CAUTI. The pooled result did not show a significantly different incidence of CAUTI between the two groups which is in line with the present study.

\section{Conclusion}

The present study concluded that chlorhexidine and soap and water was the best methods that can be used in perineal and urethral care before urinary catheter insertion and the maintenance of it after its insertion than povidone iodine solution. The present study concluded also that following CAUTI bundle of prevention will reduce the incidence of UTI among critical patients.

\section{Recommendations \\ For patients}

1- Using soap and water or chlorhexidine for perineal care before urinary catheter insertion will reduce CAUTI.

2- Every patient should be assessed for the presence of HAI at regular intervals

\section{For nurses}

1- Designing and implementing an educational training program for nurses to improve their quality of care.

2- Nurses should be evaluated for applying of standard of infection prevention and control precautions daily.

3- Every hospital should have standardized guide lines to prevent HAI according to their finance.

4- Every ICU should prepare posters about CDC guidelines for all patients undergoing invasive procedures.

\section{Conflict of interest}

The authors wished to have a large sample to apply the different solutions and also we need to include it in another hospital specialty and ICUs. The time, and funding factor did not allow for this to apply so authors wishes the future researchers will be able to apply the different solutions in a large sample and in different ICU specialty.

\section{Source of funding}

The authors did not have any university or institutional sources of fund; the research process were completely done from their own personal money source.

\section{Reference}

[1]. Nadim Cassir M, Guillemette Thomas, Sami Hraiech M, Julie Brunet, Pierre-Edouard Fournier D, Bernard La Scola M, Laurent Papazian M. Chlorhexidine daily bathing: Impact on health careeassociated infections caused by gram-negative bacteria. American Journal of Infection Control 2015; 43: 640-653.

[2]. Ternavasio-de la Vega, A. Barbosa Ventura a, F. Castan o-Romero a. Sauchelli a, A. Prolo Acosta a, F.J. Rodri'guez Alca'zar a, A. Vicente Sa'nchez a, E. Ruiz Antu'nez c, M. Marcos a,b, J. Laso. Assessment of a multi-modal intervention for the prevention of catheter-associated urinary tract infections. Journal of Hospital Infection (2016); 94: 175- 181.

[3]. Yulong Caoa, Zhizhong Gongb, Jiao Shanc, Yan Gaoa. Comparison of the preventive effect of urethral cleaning versus disinfection for catheter-associated urinary tract infections in adults: A network meta-analysis International Journal of Infectious Diseases 76 (2018) 102-108homepage: www.elsevier.com/locate/ijid https://doi.org/10.1016/j.ijid.2018.09.008

[4]. Vincitorio D, Barbadoro P, Pennacchietti L, Pellegrini I, David S, Ponzio E, et al. Risk factors for catheterassociated urinary tract infection in Italian elderly. Am J Infect Control [Internet]. 2014;42(8): 898-901. Available from: http://dx.doi.org/10.1016/j.ajic.2014.05.006.

[5]. Galiczewskia,b, Kathleen M. Shurpina. An intervention to improve the catheter associated urinary tract infection rate in a medical intensive care unit: Direct observation of catheter insertion procedure. Intensive and Critical Care Nursing (2017); 40: 26-34.

[6]. Lai C-C, Lee C-M, Chiang H-T, Hung C-T, Chen Y-C, Su L-H. Implementation of a national bundle care program to reduce catheter-associated urinary tract infection in high-risk units of hospitals in Taiwan. $\mathrm{J}$ Microbiol Immunol and Infect [Internet]. 2017; (50) 4: 464-470. https//: doi.org/10.1016/j.jmii.2017.01.006.

[7]. Liu, Yan MM; Xiao, Dong MM*; Shi, Xiao-hui MM Urinary tract infection control in intensive care patients Medicine: September 2018 - Volume 97 - Issue 38 - p e12195 doi: 10.1097/MD.0000000000012195

[8]. Düzkaya, D. S., Uysal, G., Bozkurt, G., Yakut, T., \& Çitak, A. (2017). Povidone-Iodine, 0.05\% Chlorhexidine Gluconate, or Water for Periurethral Cleaning Before Indwelling Urinary Catheterization in a Pediatric Intensive Care. Journal of Wound, Ostomy and Continence Nursing; 44(1): 84-88.

[9]. Michelle Clark and Mary-Doug Wright Antisepsis for Urinary Catheter Insertion: A Review of Clinical Effectiveness and Guidelines CADTH Rapid Response Report: Summary with Critical Appraisal Ottawa (ON): Canadian Agency for Drugs and Technologies in Health; 2019 Jan 9. Copyright (C) 2019 Canadian Agency for Drugs and Technologies in Health. 
[10]. Clayton JL. Indwelling Urinary Catheters: A Pathway to Health Care-Associated Infections. Aorn, journal. 2017;105(5): 446-52.

[11]. Centers for Disease Control and Prevention. "Urinary tract infection (catheter-associated urinary tract infection [CAUTI] and non-catheter-associated urinary tract infection [UTI]) and other urinary system infection [USI]) events." Device-associated Module CAUTI (2015).

[12]. Wilson, Peter WF. "Overview of established risk factors for cardiovascular disease." UpToDate Updated 13 (2018).

[13]. G. Bonkat (Co-chair), R. Pickard (Co-chair), R. Bartoletti,T. Cai, F. Bruyère, S.E. Geerlings, B. Köves, F. Wagenlehner,Guidelines Associates: A. Pilatz, B. Pradere, R. Veeratterapillay. EuropeaEAU Guidelines on Urological Infections. EAU Guidelines. Edn. presented at the EAU Annual Congress Copenhagen 2018. ISBN 978-94-92671-01-1.

[14]. Brett G Mitchell,1,2 Oyebola Fasugba,1,3 Anne Gardner,4 Jane Koerner,4 Peter Collignon,5,6 Allen C Cheng,7,8 Nicholas Graves,9 Peter Morey,10 Victoria Gregory1 BMJ Open Reducing catheter-associated urinary tract infections in hospitals: study protocol for a multi-site randomized controlled study : first published as 10.1136/bmjopen-2017-018871 on 28 November 2017. Downloaded from http://bmjopen.bmj.com/ on January 27, 2020 at Library Serials. doi:10.1136/bmjopen-2017-018871.

[15]. Letica-Kriegel, Allison S., et al. "Identifying the risk factors for catheter-associated urinary tract infections: a large cross-sectional study of six hospitals." BMJ open 9.2 (2019).

[16]. Duygu Sönmez Düzkaya, Gülzade Uysal,, Gülçin Bozkurt, Tülay Yakut. Povidone-Iodine, 0.05\% Chlorhexidine Gluconate, or Water for Periurethral Cleaning Before Indwelling Urinary Catheterization in a Pediatric Intensive Care: A Randomized Controlled. Article in Journal of WOCN • January 2017 DOI: 10.1097/WON.0000000000000280 J Wound Ostomy Continence Nurs. 2017;44(1):84-88. Published by Lippincott Williams \& Wilkins.

[17]. Tucson Medical Center, Tucson. Healthcare Infection Control Practice Advisory Committee (HICPAC). Guidelines for the prevention of catheter associated urinary tract infections. Accessed 25 Feb 2017 at www.cdc.gov/infectioncontrol/pdf/guidelines/cauti-guidelines.pdf $\quad$.From the, AZ http://web.mhanet.com/cauti-implementation_guide_508.pdf.

[18]. Clark, Michelle, and Mary-Doug Wright. "Antisepsis for Urinary Catheter Insertion: A Review of Clinical Effectiveness and Guidelines." (2019).

[19]. Gould CV, Umscheid CA, Agarwal RK, Kuntz G, Pegues DA, Committee HICPA. Guideline for prevention of catheter-associated urinary tract infections. Infection Control \& Hospital Epidemiology 2017; 31(4): 319 26.

[20]. Elham vahabi, Isfahan University of Medical Sciences, somayeh ghafari somayehghafari@nm.mui.ac.ir, Isfahan University of Medical Sciences 10\% povidone-iodine versus 2\% chlorhexidine gluconate for Periurethral cleansing before catheterization among hospitalized patients: A randomized controlled trial 2018. ORCiD: 0000-0001-9331-0902 somayeh haghighat Isfahan University of Medical Sciences. DOI: $10.21203 / \mathrm{rs} .2 .14793 / \mathrm{v} 1$.

[21]. Hua-ping Huang1, Bin Chen2, Hai-Yan Wang1, and Me He.The efficacy of daily chlorhexidine bathing for preventing healthcare-associated infections in adult. intensive care units Korean J Intern Med 2016; 31:1159$1170 \mathrm{https} / /$ doi.org/10.3904/kjim.

[22]. Thomas Fekete MSBC, MD.Allyson Bloom, MD. Catheter-associated urinary tract infection in adults. Jan 25, 2018.18.Wikström M, Levi R, Antepohl W. Bladder irrigation with Chlorhexidine reduces bacteriuria in persons with spinal cord injury. Journal of rehabilitation medicine. 2018;50(2):181-4.

[23]. Kara A, Özyürek P. The effect of periuretral care and follow-up on bacteriuria in patients with urinary catheter: A comparison of three solutions. Journal of Clinical and Experimental Investigations 2017; 8 (2): $62-9$.

[24]. Madeleine Wikström, RN, MSc1, Richard Levi, MD, PhD, MBA1,2 and Wolfram Antepohl, MD, PhD1,2. BLADDER IRRIGATION WITH CHLORHEXIDINE REDUCES BACTERIURIA IN PERSONS WITH SPINAL CORD INJURY. Journal of Rehabilitation medicine. J Rehabil Med 2018; 50 (2): 181-184.

[25]. Richard Levi, Wolfram Antepohl. Bladder irrigation with Chlorhexidine reduces bacteriuria in persons with spinal cord injury Article in Journal of Rehabilitation Medicine • January 2018 J Rehabil Med 2018; 50: 181184: DOI: 10.2340/16501977-2298.

[26]. Fasugba O, Koerner J, Mitchell BG, Gardner A. Systematic review and meta-analysis of the effectiveness of antiseptic agents for meatal cleaning in the prevention of catheterassociated urinary tract infections. Journal of Hospital Infection. 2017;95(3):233-42.

[27]. Laan BJ , Geerlings SE Non-antibiotic prevention strategies against catheter-associated urinary tract infections. Lancet Infect Dis. 2019; 19: 562-564. 